\title{
The Effect of Price and Service Quality on Customer Satisfaction in Mutiara Hotel Bandung
}

\author{
Dr. Ir. Bob Foster, M.M. \\ University of Informatics and Business of Indonesia, (UNIBI)
}

Ad_ariell@yahoo.com

\begin{abstract}
Competition of hotel business in Singapore is now getting stricter. Every manager must be able to understand the desires of the consumer. Customer satisfaction is a very important factor in the survival of the company. It also must be supported by price and good service quality. Giving good quality of service as well as offering low price can satisfy consumers. The primary mission for the company in deciding a strategy to win the competition is the main capital that can attract customer satisfaction to stay in the hotel. The aim of this study is to determine how consumers' assessment of price and service quality offered by Hotel Mutiara Bandung and to find how much the effect of the two variables on customer satisfaction either partly or entirely. The method in this research applies a descriptive analysis and verification and questionnaire given to 110 consumers of Mutiara hotel. Hypothesis testing is done through statistical tests. The result of the research indicates that the two variables have significant effects in the amount of 3.86 to the price variable; 3.54 for the variable service quality. While in the effect of price, the quality of service to customer satisfaction of $43.5 \%$, and $56.5 \%$ is influenced by other variables that are not examined.
\end{abstract}

Keywords: Price, quality of service, and customer satisfaction

\section{INTRODUCTION}

Business competition in the present era is increasingly high. It can be a challenge and a threat to businessmen to win the competition and maintain the viability of the company. More and more manufacturers involved in fulfilling consumers' needs and desires force companies to put orientation on customers satisfaction as a primary goal (Tjiptono, 2004: 24). It also requires businessmen to be able to maximize the performance a company in order to compete optimally with other businessmen engaged in the same field. Companies should strive to learn and understand the needs and desires of its customers. By understanding the needs, desires and demands of customers, it will provide important input for the company to design a marketing strategy in order to create satisfaction for its customers (Kotler and Armstrong, 2001).

The most important factor today is how to create customers satisfaction, as a main key of a company to win the competition by providing value and satisfaction to them by giving quality products and services at competitive rates. In the business world, if a company cannot arrange business and marketing strategies appropriately, it will lose its business. The marketing strategy is one of the main activities that can be done by employers in order to survive, thrive and obtain profit. If a company is not able to put customers satisfaction as the primary goal, it must be ready to be abandoned by them.

There is a wise word saying that a customer likened to a king who must be served, but it does not mean to give everything to customers. An effort to satisfy them needs to be done profitably or a "win-win solution", that is, 
both parties feel happy or no one is disappointed since their satisfaction is a very valuable thing for the sake of maintaining their existence in running a business or a company.

No exception to business competition is running services, namely, a hotel business. Hotel is a company managed by its owner to provide meal and drinks service as well as room facility to stay for those who are traveling and are able to pay with a reasonable amount of money in accordance with the service received in the absence of a special agreement (AgusSulastiyono 2006: 5).

This business is very profitable and can be used as an investment in the future is that quite promising. In running a competitive hotel business service, managers should consider customers satisfaction as one of the crucial aspects that should be in a top priority because consumers today are smarter in choosing a hotel or place to stay in regarding their expectations.

Mutiara Hotel Bandung is a company in the field of service. It is a three-star hotel that has been established in Singapore since 1976. It stands on land about 2.5 hectares located at Jalan Kebon Kawung No. 60 Bandung.

Its strategic location is in the city center and near Bandung station so the hotel is much in demand. Guests staying in this hotel are not only domestic but also foreign tourists because of its place easily accessible. It has five floors consisting of 101 rooms with several other facilities, such as, restaurant, pool, meeting room, and a spacious parking lot. It is well-known for its adequate facilities and low prices.

The definition of service quality can be interpreted as an effort to fulfill costumers ' needs and desires and accuracy in giving information in order to meet their expectations (Tjiptono, 2007). The quality is an effort to fulfill their convenience, therefore, they feel appreciated that is more than expected. With a good quality of service, indirectly their satisfaction will be obtained. If they are satisfied, they will call on again, even the they may recommend it to others.

Service quality can be determined by comparing consumers' perception on the services they receive or they get from excellent services that they expect or want from attributes of company's services. If the perceived services are as expected, their quality is good and satisfactory. If the received services exceed their expectations, the perceived service quality is superb. Conversely, if the received services are lower than expected, the perceived service quality is poor. Besides the service quality, other significant factor for sale is price.

In his book Djaslim Saladin (2007: 95), he states that the definition of price is an amount of money as a medium of exchange to acquire products or services. Many companies are paying less attention to this factor by setting price too high so that the company could not survive a long period or out of business because that does not fix the price according to the market. Price is set to be in accordance with the consumers' economy, so that they can buy goods. As for them, ,price is a consideration in making a purchase decision. According to Walton (2004: 17) the price of a product affects their perception regarding these products.

Price and quality have high impact on customer satisfaction; still, there is little empirical evidence exploring this relationship. This is one factor that is less noticed by the company, so that consumers will rethink to use the product and will be dissatisfied after buying or using goods or services. 
American Research Journal of Humanities and Social Sciences (ARJHSS)

Tabel 1. The Level of Room Hotel Occupancy Rate (TKP)in Star Hotel in Bandung, West Java in January 2014, December 2014, and January 2015

\begin{tabular}{|c|c|c|c|}
\hline \multirow{2}{*}{ Clasification } & \multicolumn{3}{|c|}{ TPK (in Percentage) } \\
\cline { 2 - 4 } & January2014 & December 2014 & January 2015 \\
\hline$[1]$ & {$[2]$} & {$[3]$} & {$[4]$} \\
\hline Star Hotels & $\mathbf{4 0 , 4 8}$ & $\mathbf{4 9 , 1 4}$ & $\mathbf{4 6 , 2 6}$ \\
Star 1 & 39,40 & 47,64 & 54,12 \\
Star 2 & 45,74 & 44,48 & 43,81 \\
Star 3 & 40,62 & 48,78 & 47,09 \\
Star 4 & 37,13 & 49,61 & 53,31 \\
Star 5 & 42,30 & 60,80 & 54,02 \\
\hline
\end{tabular}

Source: Jabar.bps.go.id 2015

It can be seen from table 1.1 The number of hotel guests at three-star hotels in West Java has increased. The increasing of people's willingness to stay in three star -hotels can be affected by increasing the number of three-star hotels.

Table 2. The List Three Star Hotels in Bandung

\begin{tabular}{|c|c|c|}
\hline No. & Name of Hotel & Address \\
\hline 1 & Grand Sovia Hotel & Jl. KebonKawung no. 16, Bandung Jawa Barat 40171 \\
\hline 2 & Zodiak Hotel & Jl. Pasirkaliki No. 50, Bandung Jawa Barat \\
\hline 3 & Guci Hotel & JlPasirkaliki No. 53-55, Bandung Jawa Barat \\
\hline 4 & Cemerlang Hotel & Jl. HOS Tjokokroaminoto No.45 Bandung, Jawa Barat \\
\hline 5 & Serena Hotel & Jl. KebonKawung, Bandung \\
\hline 6 & D’Batoe Hotel & Jl. PasirKaliki, Bandung \\
\hline
\end{tabular}

Source: The writer's data in 2016

With the increased competition in business hotel in Bandung, every manager should be able to understand the desires of the consumers. Giving good service and satisfying customers are core missions for a hotel where their satisfaction as a main focus for many companies in deciding the strategy to win the competition. Cheap price supported by good facility also becomes the primary capital to be able to attract them to stay.

Service quality in this study is all kinds of services provided by the hotel for guests or customers staying in the hotel, such as, service provided by the receptionist, bell boy, room service, security, cleaning service, and others. In this study, researcher aims to find how far prices can influence the consumer's decision to stay. Furthermore, it is intended to seek services provided by the hotel that will influence the consumer's decision in staying at the hotel.

\section{OBJECTIVES OF THE RESEARCH}

The research aims to study and analyze how consumers' assessment of the hotel on the price and service quality on their satisfaction in Mutiara Hotel Bandung. 


\section{CONTRIBUTION}

\section{Theoretical Contribution}

The result of this study is expected to broaden marketing study, especially, regarding the effect of price and quality of service on customers satisfaction as well as to provide input for researchers in developing the study of marketing.

\section{Practical contribution}

In practice, the result of this study is expected to be motivation and input for hotel entrepreneurs in and outside Bandung in order to improve service quality, customers' satisfaction by offering easily accessible price, and survival service product in the market.

\section{THEORETICAL FRAMEWORK}

\section{Price Concept}

Price is the value of a good or service that is expressed in money, the price also describes the amount of money which must be issued a consumer to obtain one product. Also, the price should be affordable for consumers. From a number of price definition given by experts say above, it can be concluded that price is the amount of money that must be spent by them as a substitute or exchange to obtain a number of goods and services or benefits of the product or service that will be obtained by them. Price can also be regarded as determining the value of a product or service.

Pricing objective is very important to a company before the company launchs its products to market.

According Djaslim Saladin (2006: 142), there are five goals that can be achieved by a company through pricing, namely

\section{Survival}

In certain circumstances (for their idle capacity, intense competition or changes in consumer desires, or perhaps also financial difficulties), the company sets a sales price under the total cost of the product or under market price. The goal is to survive in the short term. To survive for the long term, they have to find another way out.

\section{Maximizing short-term profit (maximum current profit)}

A company believes that with a high sales volume will lead to lower unit costs and higher profits. It sets price as low as possible assuming that the market is very sensitive to price. This is called " market penetration pricing".

This can only be done if

a. the market is very sensitive to price, and the low price is very stimulating market growth

b. the production cost of distribution decreases with increasing production.

c. The low prices will weaken the competition.

\section{Maximizing sales revenue (maximum current revenue)}

To maximize sales results, companies need to understand the demand function. Many companies argue that maximizing the sales result will drive them to obtain maximal profit in the long term and growing market section. 
Skimming market as a maximum (maximum market skimming)

Many companies set price to skim market (market skimming price). This is done to attract new segments. At first when they markets new products with high price, they then they market new products with high price. Sometime later, they also launch the same product at a lower price.

Of the several theories and explanations above, it can be elaborated that price indicators consist of (Stanton, 2005: 308)

Certainty of Price

Price is often used as an indicator of quality for consumers. For example, if there is goods or service that is expensive, they tend to assume that the goods or service has good quality. The price level of a service to one another is sometimes different as it is based on caused factors. The price expected for a service is the value with the result of the services offered.

\section{Termsofpayment}

Relates to how the consumers will pay for the product and services that will be purchased. It is usually in the form of cash or credit, depending on the policy of the organization.

\section{THE CONCEPT OF SERVICE QUALITY}

Service quality is a level of excellence that one feels for a service that the consumers they expect from comparison between their desire and perceived performance after getting the services.

Five dimensions used to measure the quality of services, namely

1) Tangibles, that is, the physical performance of a company, such as, facilities, personnel performance, and communication material.

2) Reliability, that is, the ability of company to provide services as mentioned are accurately and reliably.

3) Responsiveness, that is, a willingness to help and provide a responsive and appropriate service to the customers by giving clear information.

4) Assurance and certainty, that is, knowledge of politeness and the ability of employees to foster guests' trust to the company.

5) Empathy, that is, giving a genuine and private concern to guests by trying to find out their desires.

According Wolkins, et al in Tjiptono (2004: 73) six basic principles in the quality of services include

\section{Leadership}

Strategy of company's quality should be an initiative and commitment of top management. The top management should lead the company to improve its quality performance. Without it, the effort to improve the quality has little impact on the company

\section{Education}

All personnel of the company from top managers to operational employees must receive education about quality. Aspects that need to be emphasized on the study consists of quality concept as a business strategy, tools, and techniques of quality strategy implementation, and role of the executive in the implementation of quality strategy 


\section{Planning}

Strategic planning process should include measurement and quality goals used in directing a company to achieve its vision.

\section{Review}

The review process is the only effective tool for management to change organizational behavior. This process is a mechanism that ensures its constant attention to achieve quality goals.

\section{Communication}

Implementation of quality strategy in an organization affected by the communication process within the company. Communication should be done with employees, customers and other company stakeholders, such as suppliers, shareholders, governments, civil society, and others.

\section{AwardsandRecognition}

Awards and recognition is an important aspect in the implementation of quality strategy. Each of the employees who performs well should be rewarded and his/her achievement is recognized. Hence, it can improve motivation, morale, pride, and a sense of ownership of each person in the organization, which in turn can make a major contribution to the company and for customers served.

\section{Concept of Customer SATisfaction}

Consumers satisfaction basically cover the difference between expectations and perceived performance or results. Their assessment have three different forms, namely

- Positive disconfirmation, where the performance is better than expectation

- Simple confirmation, where the performance is the same as expectation

- Negative disconfirmation, where performance is worse than expectation.

Consumers satisfaction can be created through quality and service

Quality

Quality has a close relationship with the customers satisfaction. The quality will encourage them to establish close relationships with the company. In the long term, this bond allows it to understand their expectations and needs. Their satisfaction will ultimately create their loyalty to companies giving them a satisfactory quality.

\section{Customer service}

Customer service is not only answering consumers' questions and complaints about a product or service that does not satisfy them, but also solving arising problem after purchase.

Hawkins and Lonney cited in Tjiptono (2004: 101) state that attributes forming satisfaction are as follows

\section{compliance expectation}

It shows the degree of correspondence between performance of products expected and perceived by consumers, namely

a. the obtained products meet or exceed their expectation.

b. services given by employees match or exceed their expectation.

c. supporting facilities obtained by consumers meet or exceed their expectation. 
interests to visit again

It shows the willingness of consumers to visit again or re-purchase of the related products include

a. their interest to come back due to the satisfying services provided by the employees.

b. their interest to come back because of the value and benefits gained after consuming the product.

c. their interest to come back for supporting facilities that are provided adequately

willingness to recommend

It shows a consumer's willingness to recommend products that have been obtained to his/her friends or relatives, namely:

a. Recommending friends or relatives to buy the offered products for satisfying service.

b.Recommending friends or relatives to buy the offered products due to adequate supporting facilities.

c. Recommending friends or relatives to buy the product because the value or benefit obtained after taking a service.

\section{HYPOTHESIS}

Based on the description above, there are three hypotheses framework in this study, namely:

a. The price affects customer satisfaction.

b. Quality of service affects customer satisfaction

c. The price and service quality affect customer satisfaction.

\section{METHOD}

\section{Data Analysis Techniques}

Multiple Regression Analysis

Regression analysis aims to predict a dependent variable value with the change of an independent variable. In a multiple regression analysis, there are some variables: the predicted variables (dependent variable) is $(\mathrm{Y})$ and consumer satisfaction (independent variable) that influences, is price (XI) and service quality is (X2). Regression equations for the two predictors are: $\mathrm{Y}=\mathrm{a}+\mathrm{b} 1 \mathrm{x} 1+\mathrm{b} 2 \mathrm{X} 2$

\section{Description}

$\mathrm{Y}=$ subjects in the dependent variable in predicator

$\mathrm{a}=$ price of $\mathrm{Y}$ if $\mathrm{X}-0$ (constant)

bi b2 = Figures direction or regression coefficient showing an increase or decrease in the dependent variable that is based on the independent variable when $b(+)$ then good, if $b(-)$ then a decline

$\mathrm{Xi}$ X2 = Subject to the independent variable that have a specific value

\section{Analysis of Multiple Correlation Coefficient}

Correlation analysis aims to determine the relationship of two or more variables. This study used two independent variables, namely (X1) and (X2) and one dependent variable (Y). The intended multiple correlation is a relationship among variable price, service quality, and customer satisfaction. Formula correlation of two 
variables is shown by the formula

$$
R_{x 1 x 2 y}=\sqrt{\frac{r^{2} x^{1} Y+r^{2} x^{2} Y-2\left(r X^{1} Y\right)\left(r X^{2} Y\right)}{1-r^{2} X 1 X 2}}
$$

(Source: Sugiyono, 2013: 256)

Where:

RyXı X2 = Correlation between variable X1 and the Y

$\mathrm{rXIY}=$ Correlation between product moment variable $\mathrm{X} 1 \mathrm{and} \mathrm{Y}$

$\mathrm{rX} 2 \mathrm{Y}=$ Correlation between product moment variable $\mathrm{X} 2$ and $\mathrm{Y}$

rXIX2 = Correlation between product moment variables Xi and X2 to $\mathrm{Y}$

\section{Analysis of Determination Regression Coefficient}

The coefficient of determination is the square of the correlation coefficient. Coefficient of determination $\left(R^{2}\right)$ is used to determine how large a percentage of independent variables simultaneously influences the dependent variable, assuming $0 \leq \mathrm{r}^{2} \geq 1$. Using the formula: $K D=r^{2} \times 100 \%$ (Source: Sugiono, 2013: 328)

Where :

$\mathrm{KD}=$ coefficient of determination

$r^{2}=$ coefficient of multiple correlation

Design of Hypothesis Testing

a. Partial regression coefficient test ( $t$ test)

b. The t-test means that it tests the regression coefficient partially. According Sugiyono formula used is as follows

$\mathrm{t}_{\text {hitung }}=\frac{\mathrm{r} \sqrt{\mathrm{n}-2}}{\sqrt{1-\mathrm{r}^{2}}}$

(Source: Sugiyono, 2013: 250)

\section{Description}

$\mathrm{t}=\mathrm{t}$ counting value

$r^{2}=$ value of determination coefficient

$\mathrm{n}=$ the number of respondents

$r=$ correlation coefficient of $r$ count results

As for the null hypothesis (Ho) and alternative hypothesis (H1) in this study are as follows

Price

1. a. Ha: $\beta 1=0$ "Price has no effect on customers' satisfaction"

2. b. Hi: $\beta 1 \neq 0$ "Price affects customers' satisfaction

Quality of Service

a. H0: $\beta 1=0$ "The quality of service has no effect on customer satisfaction"

b. Hi: $\beta 1 \neq 0$ "service quality affects customer satisfaction

Regression Coefficients Simultaneous Test (Test F ${ }^{2} / f F=\left(1-R^{2}\right) /(n-k-1)$

$\mathrm{R}^{2}=$ coefficient of determination

$\mathrm{k}=$ number of independent variables 
and $=$ Number of data or case

As for the null hypothesis (Ho) and alternative hypothesis (HI) in this study are as follows

a. Ha: $\beta 1 \beta 2=0$ The price and quality of service simultaneously has no effect on customer satisfaction (Y).

b. Hi: $\beta 1 \beta 2 \neq 0$ The price and quality of service, simultaneously affects customer satisfaction (Y).

\section{FINDINGS}

Data Analysis Techniques

\section{a. The analysis of Multiple Linear Regression}

Table3. The Result of Linear Regression Test of Price (X1) and Service quality (X2) on the Customer Satisfaction ( $Y$ )

\section{Coefficients $^{\mathrm{a}}$}

\begin{tabular}{|l|c|c|c|c|c|}
\hline \multirow{2}{*}{ Model } & \multicolumn{2}{|c|}{$\begin{array}{c}\text { Unstandardized } \\
\text { Coefficients }\end{array}$} & $\begin{array}{c}\text { Standardized } \\
\text { Coefficients }\end{array}$ & \multirow{2}{*}{ t } & Sig. \\
\cline { 2 - 4 } & $\mathrm{B}$ & Std. Error & Beta & &, 170 \\
\hline (Constant) &,- 552 &, 400 & & $-1,380$ &, 000 \\
price &, 591 &, 084 &, 514 & 7,058 &, 000 \\
Service quality &, 557 &, 090 &, 450 & 6,176 &, 000 \\
\hline
\end{tabular}

Analysis:

The above table illustrates that the multiple regression equation for the data used in this study are as follows

$\mathrm{Y}=-0.552+0.591(\mathrm{xi})+0.557(\mathrm{X} 2)$

The coefficient value of the constant $\mathrm{a}=-0.552$ means that if the price variable and service quality are ignored, the value of customer satisfaction is equal to -0.552 . The regression coefficient on the variable price is 0.591 that means that if the price is increased by 1 unit, the consumer satisfaction will increase by 0.591 . So the variable quality of service is increased by 1 unit, the consumer satisfaction will increase by 0.557 .

\section{b. Analysis of Multiple Correlation Coefficient}

Table4. Correlation Coefficient of price variable (X1) and variable service quality variable (X2) to the Customer Satisfaction (Y)

\section{Correlations}

\begin{tabular}{|c|c|c|c|c|}
\hline \multicolumn{2}{|c|}{} & $\begin{array}{c}\text { Consumer } \\
\text { Satisfaction }\end{array}$ & Price & Service quality \\
\hline \multirow{3}{*}{ Pearson Correlation } & Satisfaction of & 1,000 &, 484 &, 415 \\
\cline { 2 - 5 } & Consumer Price &, 484 & $1,000-$ &, 0671 \\
\cline { 2 - 5 } & Service Quality &, 415 &, 067 &, 1000 \\
\hline \multirow{3}{*}{ Sig. (1-tailed) } & Consumer satisfaction &. &, 000 &, 000 \\
\cline { 2 - 5 } & price &, 000 &, &, 243 \\
\cline { 2 - 5 } & Service quality &, 000 &, 243 & 110 \\
\hline \multirow{2}{*}{$\mathrm{N}$} & Costumer satisfaction & 110 & 110 & 110 \\
\cline { 2 - 5 } & price & 110 & 110 & 110 \\
\cline { 2 - 5 } & Service quality & 110 & 110 & \\
\hline
\end{tabular}

Source: data processing, 2015 
Based on the above table, it can be conclude that the number of price correlation to customer satisfaction is at 0.484 , while the correlation of service quality on customer satisfaction is 0.415 .

\section{c. The analysis of multiple determination coefficient}

Table5. Coefficient of Determination Regression Price (X1) and quality of service (X2) on the Customer Satisfaction $(Y)$

\begin{tabular}{|c|c|c|c|c|}
\hline \multicolumn{4}{|c|}{ Model Summary } \\
\hline Model & R & R Square & Adjusted R Square & Std. Error of the Estimate \\
\hline 1 &, $660^{\text {a }}$ &, 435 &, 425 &, 50185 \\
\hline a. Predictors: (Constant), Service Quality, Price & & \\
\hline
\end{tabular}

Source: Data Processing, 2015) SPSS 21.0

This value indicates that the magnitude of the contribution of the independent variable is the price (X1) and quality of service (X2) in explaining or predicting the dependent variable is customer satisfaction (Y). While the influence of other factors that are not observed by the researcher is $(100 \%-43.5 \%=56.5 \%)$, which is derived from other variable rather than the variable price and quality of service.

\section{Hypothesis testing}

a. Partial hypothesis test ( $\mathrm{t}$ test) Price on Customer Satisfaction

Table 6. Test Results $t$ Influence Price (X1) on the consumer satisfaction

\section{Coefficients}

\begin{tabular}{|c|c|c|c|c|c|c|}
\hline \multicolumn{2}{|c|}{ Model } & \multicolumn{2}{c|}{$\begin{array}{c}\text { Unstandardized } \\
\text { Coefficients }\end{array}$} & $\begin{array}{c}\text { Standardized } \\
\text { Coefficients }\end{array}$ & T & \multirow{2}{*}{ Sig. } \\
\cline { 3 - 7 } \multicolumn{2}{|c|}{} & B & Std. Error & Beta & & \\
\hline \multirow{2}{*}{1} & (Constant) & 1,247 &, 318 & & 3,922 &, 000 \\
\cline { 2 - 7 } & Price of service quality &, 556 &, 097 &, 484 & 5,744 &, 000 \\
\hline
\end{tabular}

Dependent Variable: Consumer Satisfaction

Source: data processing, 2015

So that the test results obtain Tcount $>$ Ttabel (5.744> 1.659), then Ho is rejected and Hi is accepted. This means that price affects consumer satisfaction

On testing the partial curve can be depicted in the reception area, while rejection of Ho as follows:

$1,659=5,744$

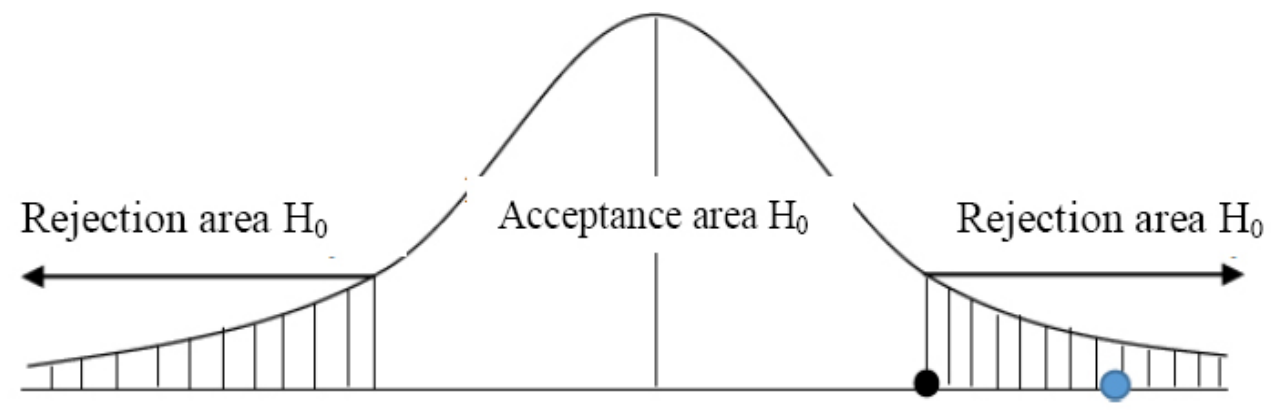

Figure 1

Volume 2 
Determination of the test area Ho partial Price (xi) of the Consumer satisfaction (Y)

It can be concluded that the price is one of the factors that influences consumer satisfaction because the price set by the company as a benchmark for it. It is because the price is one consideration for them to buy a product.

Partial Testing of Service Quality on Customer Satisfaction

Table 7. $t$ Test Result Effect of Quality of Service (X2) on Customer Satisfaction

\begin{tabular}{|c|c|c|c|c|c|c|}
\hline \multicolumn{7}{|c|}{ Coefficients $^{\mathrm{a}}$} \\
\hline \multirow[t]{2}{*}{ Model } & \multicolumn{2}{|c|}{$\begin{array}{l}\text { Unstandardized } \\
\text { Coefficients }\end{array}$} & \multirow{2}{*}{$\begin{array}{c}\text { Standardized } \\
\text { Coefficients }\end{array}$} & \multirow[t]{2}{*}{$\mathrm{T}$} & \multirow{2}{*}{\multicolumn{2}{|c|}{ Sig. }} \\
\hline & $\mathrm{B}$ & Std. Error & & & & \\
\hline (Constant) & 1,488 &, 334 & & & 4,461 &, 000 \\
\hline Service quality &, 514 &, 108 &, 415 & & 4,744 &, 000 \\
\hline
\end{tabular}

Dependent Variable: Consumer Satisfaction

Source: Data Processing 2015

The result indicates that the correlation coefficient of service quality on customer satisfaction is 0.415 . The value shows the correlation value is included in the classification of moderate or strong enough. While the magnitude of the effect of price on consumer satisfaction is $43.5 \%$ and the remaining is $56.5 \%$. These are influenced by other factors that are not examined.

\section{CONCLUSION}

Based on the data analysis and the research findings on the effect of the price and the service to consumers' satisfaction, it can be concluded as follows.

1) Assessment of consumers on the prices offered by the Mutiara Hotel is classified in a good criteria. It means that the respondents give a good or positive feedback. This is indicated by the presence of a very easy or flexible payment system.

2) Assessment of consumers on services quality provided by Mutiara Hotel is classified in a good criteria. The finding can be seen by hotel employees' statements that they are always friendly when serving them.

3) Assessment of consumers based on the price and the service quality to their satisfaction is in good or positive criteria. This is indicated by their intention to come back to use their service.

\section{REFERENCE}

Alma, Buchari (2004). Manajemen Pemasaran dan Pemasaran Jasa. Revision Edition, Bandung: Alfabetha. Arikunto, S (2010). Prosedure Penelitian: Suatu Pendekatan Praktik. Revision Edition. Jakarta: Rineka Cipta ArdhanaOldy, (2010). Analisis Pengaruh Kualitas Pelayanan, Harga dan Lokasi Terhadap Kepuasaan Konsumen Pada Bengkel Caisar Semarang: Skripsi Universitas Diponogoro Semarang.

Arman,HeruMaulana,(2008).PengaruhHargadanKualitasPelayananTerhadapKepuasanKonsumen.(StudiKasusPada Perusahaan Lion Air Cabang Padang). Other Thesis, FakultasEkonomi. UniversitasAndalan. 
American Research Journal of Humanities and Social Sciences (ARJHSS)

Amanah, Dita (2010). Pengaruh Hargadan Kualitas Produk Terhadap Kepuasan Konsumen. Jurnal Keuangan dan Bisnis Fakultas Ekonomi Universitas Medan.

BelajarSerbaneka, 2012. Konsep dan Peranan Harga diambil kembali dari http://Belajarserbaneka blogspot. com/2012/11/konsep-dan-peranan-harga.html.

Chaniago, Junaidi. 2010. Tabelr (KoefisienKorelasiSederhana). http://junaidichaniago.wordpress.com

Chaniago, Junaidi.2010.Titik Presentase Distribusit. http://junaidichaniago.wordpress.com

Cherie Maria, 2013.Pentingnya harga dalam Pemasaran diambil kembali dari marion marketing.blogspot.com

Kotler, Philip and Kevin L.Keller.2007.Manajemen Pemasaran.Edisi 12 jilid 2. PT Indeks

Kotler, Philip (2003). ManajemenPemasaran. Jakarta. PT. Indeks kelompok Gramedia.

Khudriah (2015). Pengaruh Harga dan Kualitas Pelayanan Terhadap Kepuasan Konsumen Penghuni Kosan Sumantri Di Kubangsari No.12 Kota Bandung.

LubisNurbaityArlina, 2009. Pengaruh Harga dan Kualitas Pelayanan Terhadap Kepuasan Pasien Rawat Inap di RSU Deli Medan. Jurnal Manajemen Bisnis Universitas Sumatra Utara.

Majid, (2008).pengertian-konsep-definisidiambilkembalidari

http://majiddbsz.wordpress.com/2008

Nulz, 2012. ManajemenPemasaranjasadanmanajemenBauranpemasaranjasaNulz-e.blogspot.com/2012/

Rangkuti, Freddy, (2002). Riset Pemasaran. Jakarta: PT. Gramedia Pustaka Utama.

Saladin Djaslim, (2007). Manajemen Pemasaran, Bandung; Linda Karya.

Sugiyono, (2013). Statistik Untuk Penelitian. Bandung: Alfabetha.

Sahaja, Irwan, 2013. Bauran Pemasaran Jasa. Taken from irwansahaja.blogspot.com

Tjiptono, Fandy, 2004. PemasaranJasa. Malang:Bayumedia.

Wibowo, Suasanto, Ari, 2013. Pengaruh Harga, Kualitas Pelayanan dan Nilai Pelanggan Terhadap Kepuasan Konsumen. (Studi Kasus rumah makan di Kota Purwokerto. Skripsi Universitas Negeri Semarang.

Wahyono B, 2012. Pengertian dan Pengukururan Kepuasan Konsumen. Taken from www.pendidikanekonomi.com

Citation: Dr. Ir. Bob Foster, M.M. The Effect Of Price And Service Quality On Customer Satisfaction In Mutiara Hotel Bandung, American Research Journal of Humanities and Social Sciences, Volume 2, 2016; pp:1-12

Copyright (C) 2016 Dr. Ir. Bob Foster, M.M. .This is an open access article distributed under the Creative Commons Attribution License, which permits unrestricted use, distribution, and reproduction in any medium, provided the original work is properly cited. 